\title{
Robot-Assisted Total Hip Arthroplasty for Arthrodesed Hips [Corrigendum]
}

\author{
Chai W, Kong X, Yang M, Puah KL, Tang P, Chen J. Ther \\ Clin Risk Manag. 2020;16:357-368.
}

The authors have advised that the funding statement on page 367 is incorrect. The text "This study was funded by the Beijing Municipal Natural Science Foundation
(L182063)" should read "This study was funded by the Translational Medicine Project of Chinese PLA General Hospital (2018TM-13)".

The authors apologize for this error.

\section{Publish your work in this journal}

Therapeutics and Clinical Risk Management is an international, peerreviewed journal of clinical therapeutics and risk management, focusing on concise rapid reporting of clinical studies in all therapeutic areas, outcomes, safety, and programs for the effective, safe, and sustained use of medicines. This journal is indexed on PubMed Central, CAS,
EMBase, Scopus and the Elsevier Bibliographic databases. The manuscript management system is completely online and includes a very quick and fair peer-review system, which is all easy to use. Visit http://www.dovepress.com/testimonials.php to read real quotes from published authors. 